\title{
Effects of the polychaetes Nereis diversicolor and Arenicola marina on the fate and distribution of pyrene in sediments
}

\author{
Mette Christensen ${ }^{*}$, Gary T. Banta**, Ole Andersen \\ Department of Life Sciences and Chemistry, Roskilde University, PO Box 260 (17.2), 2100 Roskilde, Denmark
}

\begin{abstract}
Effects of the polychaetes Nereis diversicolor and Arenicola marina on the distribution, metabolism and removal of $\left[{ }^{14} \mathrm{C}-4,5,9,10\right]$-pyrene in sediment microcosms were studied over 42 and $53 \mathrm{~d}$, respectively. Unmetabolized pyrene, water- and organic-soluble pyrene metabolites were quantified in sediment, interstitial water and overlying water, and ${ }^{14} \mathrm{CO}_{2}$ production was also assessed. Both $N$. diversicolor and A. marina enhanced fluxes of sediment-associated pyrene and metabolites into overlying water but to different extents. The major pathway of pyrene removal from sediments with $N$. diversicolor was release of water-soluble metabolites, probably formed by metabolism in $N$. diversicolor. In contrast, flushing of unmetabolized pyrene due to bioturbation was the major removal route from sediments with $A$. marina. Additionally, increased ${ }^{14} \mathrm{CO}_{2}$ production and concentrations of water-soluble metabolites were also observed in overlying water indicating that $A$. marina also stimulated the metabolism of pyrene. The high production of water-soluble metabolites was probably due to endogenous metabolism in the lugworm itself, whereas the increased ${ }^{14} \mathrm{CO}_{2}$ production indicated a stimulation of microbial metabolism. After $42 \mathrm{~d}$, only $75 \%$ of the originally added amount of pyrene remained associated to sediment particles in microcosms inhabited by $N$. diversicolor, whereas no significant reduction was observed in microcosms with $A$. marina due to the necessity of using large amounts of sediment in the lugworm experiment. The actual flux of pyrene and metabolites to overlying water was higher in microcosms with $A$. marina than with $N$. diversicolor. Both A. marina and $N$. diversicolor significantly enhanced the removal pyrene from the sediment, but differences in feeding and life strategies resulted in different removal paths and extents.
\end{abstract}

KEY WORDS: Pyrene - Arenicola marina $\cdot$ Nereis diversicolor $\cdot$ Budgets $\cdot$ Sediment contaminants Bioturbation $\cdot$ PAH

Resale or republication not permitted without written consent of the publisher

\section{INTRODUCTION}

Oil spills are a major source of polycyclic aromatic hydrocarbon (PAH) pollution in aquatic systems. Crude and refined petroleum compounds contain from 0.2 to more than $7 \%$ PAH (Neff 1985). It is estimated that over 400 oil spills occur annually in Danish waters alone, making PAH pollution events quite common.

\footnotetext{
*Present address: Department of Clinical Genetics, Rigshospitalet, 2100 Copenhagen Ø, Denmark

${ }^{* *}$ Corresponding author. E-mail: banta@ruc.dk
}

These PAH emissions may have long-term effects on aquatic organisms living in affected areas. PAHs are hydrophobic compounds, which rapidly associate with sediment particles. Once incorporated in the sediment, PAHs are persistent compounds and may be accessible for sediment-dwelling animals over timescales of months to years. Furthermore, PAHs with molecular weights between 128 and 202 (naphtalene-fluoranthene) have high acute toxicity toward aquatic organisms (Rossi \& Neff 1978, Neff 1985) and many of the larger PAHs are carcinogenic to vertebrates. The combination of toxicity or carcinogenicity and persistence 
stresses the importance for understanding the fate and effects of these compounds in the aquatic environment in general and in sediments in particular. A better understanding of how PAHs interact with sediment biota is especially needed given that infaunal organisms are in intimate contact with contaminated sediments and interstitial waters, and these animals may contribute to the trophic transfer of PAHs and organicsoluble metabolites through the food-web (McElroy \& Sisson 1989, Garrigues et al. 1990).

The fate of PAHs in sediment is influenced by a number of biotic and abiotic factors. Temperature, salinity (May \& Wasik 1978), $\mathrm{pH}$, sediment redox conditions (Delaune et al. 1981), organic content, the age of organic material (Means et al. 1980, Evans et al. 1990), solubility and fugacity of the individual PAHs, and the amount of light reaching the bottom (Neff 1985) all affect the incorporation, distribution and release of PAHs in sediments. The presence of biota, especially sediment-dwelling animals, also likely play an important role in the fate of PAHs in sediment. Sedimentdwelling animals are known to affect the release and distribution of hydrophobic organic compounds associated with the sediment through their bioturbating activities, particle mixing and irrigation (Gordon et al. 1978, Schaffner et al. 1997). Bioturbation leads to both continuous sediment mixing and the repeated transport of particulate material from deeper sediment layers to the surface and vice versa. In this way, sedimentadsorbed contaminants remain in contact with the overlying water for longer periods of time than in nonbioturbated sediment (Reynoldson 1987), thus enhancing the diffusive loss of contaminants from the sediment to the water. Also, burrowing enhances the surface sediment area which, together with irrigation, increases the diffusive loss of contaminants from the sediment (Gilbert et al. 1994). Furthermore, the aerobic microbial community may be stimulated by irrigation and burrowing activity of tube-dwelling organisms as penetration of oxygen increases, thereby enhancing aerobic zones in sediments (Krantzberg 1985). This effect could be especially important for the microbial breakdown of persistent compounds such as PAHs, which degrade either slowly or not at all under anaerobic conditions (Neff 1985). The presence of polychaetes in contaminated sediment has been shown to enhance microbial mineralization of PAHs in the sediment (Bauer et al. 1988, McElroy et al. 1990). Finally, PAHs may be metabolized in an organism's tissues and thereby removed from the sediment.

The purpose of this study was to examine the effects of infaunal organisms on the flux and metabolism of sediment-associated PAHs using $\left[{ }^{14} \mathrm{C}-4,5,9,10\right]$-pyrene as a model compound and the polychaetes Arenicola marina and Nereis diversicolor as model organisms in experimental microcosms. These polychaetes were chosen as they are common members of the benthic community in coastal areas of Europe. Additionally, they co-exist in nature but have different feeding and behavioral strategies. The lugworm A. marina lives in a J-shaped tube at densities up to 150 ind. $\mathrm{m}^{-2}$ (Dankers et al. 1981). It is generally regarded as a nonselective head-down deposit feeder and ingests large amounts of sediment in the subsurface and pumps extensive amounts of water through its feeding funnel (Wells 1966, Riisgård \& Banta 1998). This feeding strategy causes extensive bioturbation of sediment particles to depths of $15 \mathrm{~cm}$ or more. In contrast, $N$. diversicolor is considered mainly as an omnivorous or a surface deposit feeder (Fauchald \& Jumars 1979); however, it is also capable of filter-feeding when algae are present in the overlying water (Vedel 1997). $N$. diversicolor lives in U-shaped tubes at densities of up to 4000 ind. $\mathrm{m}^{-2}$ (Kristensen 1984, 1988) and is not as active a particle mixer as A. marina. $N$. diversicolor, however, irrigates more intensively than $A$. marina (Kristensen 1983, Riisgård et al. 1996). As a result of the U-shaped tube formed by $N$. diversicolor irrigating, water is rapidly transported through the tube and back into overlying water. Loss of contaminants from $N$. diversicolor-bioturbated sediment is thereby due to diffusive effects and enhanced solute exchange between interstitial water and the burrow (Gilbert et al. 1994).

Irrigation by Arenicola marina is more moderate but occurs in a fundamentally different way. The water pumped through the lugworm's burrow is injected into the sediment at the feeding pocket, and returns to the surface by advective flow through the sediment of the feeding funnel, which results in a flushing and oxidation of interstitial water (Hüttel 1990, Banta et al. 1999). Finally, Nereis diversicolor is known to metabolize PAHs, probably catalyzed by cytochrome P-450 (CYP activity) (Driscoll \& McElroy 1996), while CYP activity has not been reported in A. marina (Payne \& May 1979). These differences in physiology, bioturbation, metabolic capacity and behavior between A. marina and $N$. diversicolor are expected to have different effects on the fate and turnover of PAHs in sediments.

The goal of this study was to investigate the distribution of pyrene and its metabolites as well as the formation of $\mathrm{CO}_{2}$ liberated from pyrene due to microbial metabolism in sediment microcosms with and without Arenicola marina or Nereis diversicolor in order to examine the effects of these 2 polychaetes on the fate of PAHs in the sediment. By quantifying remobilization, metabolism and mineralization of a relevant model PAH in closed microcosms with and without $A$. marina or $N$. diversicolor, it would for the first time be possible to calculate cumulative ${ }^{14} \mathrm{C}$-budgets, and 
thereby predict the main mechanisms and pathways for turnover of PAHs in coastal areas dominated by these polychaete species. In particular, we wished to study whether $N$. diversicolor or A. marina enhanced the removal of pyrene from the sediment, and if so, to determine the importance of polychaete metabolism and irrigation activity versus bacterial metabolism.

\section{MATERIALS AND METHODS}

Collection and preparation of sediment and worms. Sediment, Arenicola marina and Nereis diversicolor were collected in Roskilde Fjord (Denmark) from a site with high densities of both polychaete species. $N$. diversicolor was collected in the spring and A. marina in autumn of 1999, due to limitations in laboratory capacities. Sediment was passed through a $1 \mathrm{~mm}$ mesh sieve to remove large particles and frozen at $-18^{\circ} \mathrm{C}$ to kill meio- or macrofauna prior to contamination with pyrene. Sediment organic matter content in both sampling sessions was $0.17 \pm 0.03 \%$, which was determined by loss of ignition at $550^{\circ} \mathrm{C}$ after $24 \mathrm{~h}$. Worms were acclimated for $8 \mathrm{~d}$ at $15^{\circ} \mathrm{C}$ in uncontaminated sediment and $16 \%$ seawater before being transferred to pyrene-contaminated sediment microcosms.

Contamination of sediment. Sediment was contaminated with $\left[{ }^{14} \mathrm{C}-4,5,9,10\right]$-pyrene (SIGMA, specific activity $250 \mathrm{nCi} \mathrm{mmol}^{-1}$, purity $>98 \%$ ) to a specific activity of ca. $8 \mu \mathrm{Ci} \mathrm{kg}^{-1}$ (wet wt) and with nonradioactive pyrene (ALDRICH, purity $>98 \%$ ) to a concentration of $400 \mathrm{ppb}$ pyrene. To remove labeled degradation products in the stock solution of pyrene before use, a mixture of labeled and unlabeled pyrene in acetone was purified by evaporating acetone and using the extraction procedure described below for separation of unmetabolized pyrene and organic-soluble pyrene metabolites. After evaporation of hexane to near dryness, pyrene was resuspended in $10 \mathrm{ml}$ acetone, and this solution was added slowly with stirring to $0.5 \mathrm{~kg}$ air-dried sediment. After evaporation of the acetone ( 3 to $4 \mathrm{~h}$ ), wet sediment was added with stirring either by hand or in an electric mixer. Homogeneous mixing of ${ }^{14} \mathrm{C}$ pyrene into the sediment was confirmed by measuring the radioactivity in 6 sub-samples $(\mathrm{CV}<10 \%)$.

Experimental set-up. For both experiments microcosms consisted of plastic core tubes filled with ${ }^{14} \mathrm{C}$ pyrene-contaminated sediment and $16 \%$ seawater. Both experiments were conducted at $15^{\circ} \mathrm{C}$, and ambient air was pumped continuously through the water column.

Nereis diversicolor: Twenty-eight core tubes (diameter $5.2 \mathrm{~cm}$, height $20 \mathrm{~cm}$ ) were filled with 0.301 sediment and $80 \mathrm{ml}$ seawater. One Nereis diversicolor $(0.45 \pm 0.11 \mathrm{~g}$ wet $\mathrm{wt})$ was added to each core tube, equivalent to a density of 471 worms $\mathrm{m}^{-2}$. An additional 21 core tubes were established without $N$. diversicolor. Overlying water was changed every $5 \mathrm{~d}$, and the water from 4 microcosms with and 3 without $N$. diversicolor was analyzed for unmetabolized pyrene, ${ }^{14} \mathrm{CO}_{2}$, waterand organic-soluble pyrene metabolites (see next subsection). To trap ${ }^{14} \mathrm{CO}_{2}, 4$ microcosms with and 3 microcosms without worms were each sealed with stoppers and coupled to 2 serially connected test tubes each containing $15 \mathrm{ml} 0.5 \mathrm{M} \mathrm{NaOH}$. Trapping efficiency was $>90 \%$ tested with ${ }^{14} \mathrm{C}-\mathrm{NaHCO}_{3}$. To prevent starvation, $5 \mathrm{~h}$ before water change ca. $0.2 \mathrm{~g}$ Tetra $\mathrm{Min}^{\circledR}$ fish food was added to core tubes containing $N$. diversicolor. After 1, 3, 5, 10, 15, 28 and $42 \mathrm{~d}, 4$ microcosms with $N$. diversicolor and 3 microcosms without were terminated and amounts of unmetabolized ${ }^{14} \mathrm{C}$-pyrene, water- and organic-soluble metabolites determined in overlying water, interstitial water and sediment (see following subsections). At water change, ${ }^{14} \mathrm{CO}_{2}$ production and released pyrene and derived compounds were determined in overlying water for the same microcosms by liquid scintillation counting (LSC) in a Wallac LKB 1219 and samples were corrected for quenching.

Arenicola marina: A larger amount of sediment was used in the Arenicola marina than in the Nereis diversicolor experiment, as A. marina is found at lower densities and requires a deeper sediment column due to its feeding strategy. One $A$. marina $(0.57 \pm 0.08 \mathrm{~g}$ wet wt) was added to each of 30 core tubes (diameter $8.3 \mathrm{~cm}$, height $34.5 \mathrm{~cm}$ ) filled with 1.31 pyrene-contaminated sediment and $400 \mathrm{ml}$ seawater, yielding a density of 185 worms $\mathrm{m}^{-2}$. The use of small juveniles was believed to limit the stress impact of the otherwise rather high density. Twenty-eight smaller core tubes (diameter $5.2 \mathrm{~cm}$, height $20 \mathrm{~cm}$ ) containing 0.51 sediment and $155 \mathrm{ml}$ seawater were used as microcosms without A. marina. Using this experimental design, the heights of sediment and overlying water were the same in microcosms with and without A. marina. Previous work had shown that there were no differences in fluxes of pyrene products or ${ }^{14} \mathrm{CO}_{2}$ in microcosms of different diameters containing only contaminated sediment and water (data not shown). ${ }^{14} \mathrm{CO}_{2}$ was trapped by the same procedure as in the $N$. diversicolor experiment, with the exception that a cooling unit was added between the cores and ${ }^{14} \mathrm{CO}_{2}$ traps to prevent the flow of condensed water. Trapping efficiency was again $>90 \%$ tested with ${ }^{14} \mathrm{C}-\mathrm{NaHCO}_{3}$. Overlying water and ${ }^{14} \mathrm{CO}_{2}$ trapping tubes were changed and analyzed from 6 to 8 microcosms with and without worms after 3,11 , $14,24,31,38,43$ and $52 \mathrm{~d}$. In contrast to the $N$. diversicolor experiment, the production of ${ }^{14} \mathrm{CO}_{2}$ was determined for the same microcosms throughout the experiment. After 5, 14, 28 and 52 d, 3 to 6 microcosms with and without A. marina, and different from those used 
to trap ${ }^{14} \mathrm{CO}_{2}$, were terminated and analyzed in order to determine unmetabolized ${ }^{14} \mathrm{C}$-pyrene, water- and organic-soluble metabolites in the overlying water, interstitial water and sediment, respectively. On Day 43, the microcosms $(\mathrm{n}=6)$ used to measure ${ }^{14} \mathrm{CO}_{2}$ production were also terminated and analyzed for unmetabolized pyrene and pyrene metabolites in overlying water, interstitial water and sediment.

Extraction of overlying water. Before each water change, the overlying water was sampled from microcosms with and without worms to determine ${ }^{14} \mathrm{C}$-activity. Twenty-seven $\mathrm{ml}$ water was transferred directly from the microcosm to a closed vessel connected to 2 serial tubes containing $15 \mathrm{ml} 0.5 \mathrm{M} \mathrm{NaOH}$. The water was acified with $1 \mathrm{ml} 1 \mathrm{M} \mathrm{HCL}$ and bubbled with air for 5 to $10 \mathrm{~min}$, thereby trapping ${ }^{14} \mathrm{CO}_{2}$ in overlying water (efficiency >93\%). Activity of ${ }^{14} \mathrm{CO}_{2}$ in overlying water was determined by transferring $4 \mathrm{ml} \mathrm{NaOH}$ solution to vials filled with $10 \mathrm{ml}$ Packard ${ }^{\circledR}$ Ultima Gold XR alkalized with $0.4 \mathrm{ml} 4 \mathrm{M} \mathrm{NaOH}$. After stripping of ${ }^{14} \mathrm{CO}_{2}$ from the overlying water, $\mathrm{pH}$ was adjusted back to its original level $(\mathrm{pH} \approx 8)$ and $12 \mathrm{ml}$ water was extracted with $30 \mathrm{ml}$ methanol and $15 \mathrm{ml}$ chloroform by vigorous shaking to create a 1-phase system (see Fig. 1). Next, an additional $15 \mathrm{ml}$ chloroform and the remaining $15 \mathrm{ml}$ overlying water were added and the mixture shaken to obtain a separation of the watermethanol and chloroform fractions. The chloroform fraction was decanted to dark glass tubes and evaporated in a stream of air nearly to dryness. To this, $600 \mu \mathrm{l}$ DMSO (SIGMA purity >98\%), $250 \mu \mathrm{l}$ water and $150 \mu \mathrm{l}$ $1 \mathrm{M} \mathrm{KOH}$ were added. The solutions were mixed using a vortex mixer and $2 \mathrm{ml}$ hexane (purity $>98 \%$ ) added. After mixing for $30 \mathrm{~s}$ and centrifugation for $5 \mathrm{~min}$ at $250 \times g$, the hexane fraction was transferred to a new test tube. Further, $2 \mathrm{ml}$ hexane was added to the alkaline DMSO-water fraction and the procedure repeated twice. Extractions with pure compounds indicated that recovery of ${ }^{14} \mathrm{C}$-pyrene was $84 \pm 10 \%$ and that only 0.3 and $0.4 \%$ pyrene were retained in the alkaline DMSOwater and methanol-water fraction, respectively.

Samples were $\beta$-counted after transferring $3 \mathrm{ml}$ methanol-water solution, $0.6 \mathrm{ml}$ alkaline DMSO-water fraction and $3 \mathrm{ml}$ hexane extract to vials containing $10 \mathrm{ml}$ Ultima Gold XR.

Extraction of interstitial water. All sediment from a microcosm was mixed thoroughly by hand and weighed. Interstitial water and sediment were separated by transferring 3 to 4 subsamples of sediment to $20 \mathrm{ml}$ glass vials sealed with a perforated lid containing a Whatman ${ }^{\circledR}$ glass microfibre filter and inserted upside down into a centrifuge tube. Interstitial water was sampled by 2 repeated centrifugations at 250 and $500 \times g$ for $10 \mathrm{~min}$, respectively. Sampled interstitial water was extracted immediately and dry sediment was frozen at $-18^{\circ} \mathrm{C}$ for later analysis.

Nine ml interstitial water was extracted by scaling down the procedure for the extraction of overlying water. Interstitial water was acidified with $0.5 \mathrm{ml} 1 \mathrm{M}$ $\mathrm{HCl}$ and ${ }^{14} \mathrm{CO}_{2}$ trapped in $\mathrm{NaOH}$. After removal of ${ }^{14} \mathrm{CO}_{2}, \mathrm{pH}$ in the interstitial water was adjusted back to its original level and $4 \mathrm{ml}$ interstitial water was extracted with $10 \mathrm{ml}$ methanol and $5 \mathrm{ml}$ chloroform, and the solution shaken. Afterwards, an additional $5 \mathrm{ml}$ interstitial water and $5 \mathrm{ml}$ chloroform were added and mixed. The chloroform fraction was evaporated and further treated as described above.

Extraction of sediment. To approximately $2 \mathrm{~g}$ thawed sediment, $1 \mathrm{ml}$ chloroform, $2 \mathrm{ml}$ methanol and $0.8 \mathrm{ml}$ distilled water were added. The solution was vortexed for $30 \mathrm{~s}$ and sonicated for $20 \mathrm{~min}$. Afterwards, $1 \mathrm{ml}$ chloroform and $1 \mathrm{ml}$ distilled water were added to obtain a final ratio of methanol:chloroform:water of $2: 2: 1.8$. The mixture was mixed for $30 \mathrm{~s}$ followed by centrifugation for $5 \mathrm{~min}$ at $250 \times \mathrm{g}$. The fractions of methanol-water and chloroform were transferred to separate test tubes. Extraction of the sediment was further repeated twice, but with $1 / 2$ the amounts of solvents. The resulting chloroform fraction was evaporated under a stream of air and treated as described above. LSC was used to measure $3 \mathrm{ml}$ methanol-water, $0.6 \mathrm{ml}$ alkaline DMSO and $2 \mathrm{ml}$ hexane solution.

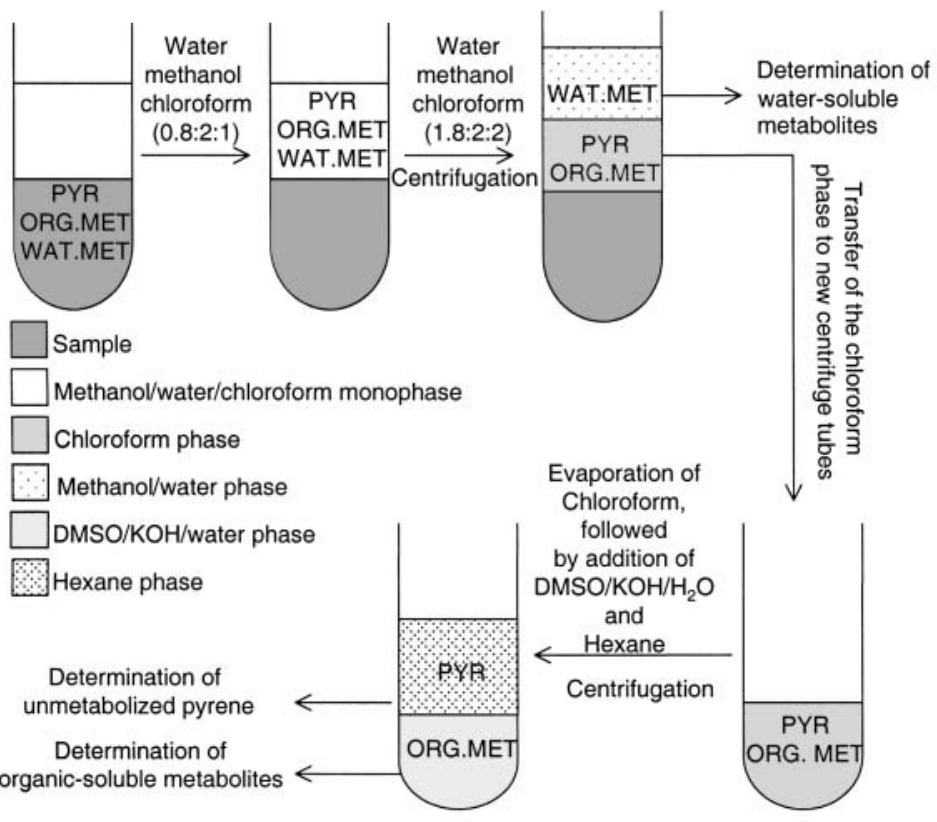

Fig. 1. Simplified illustration of the extraction procedure used to separate unmetabolized pyrene (PYR), organic- (ORG.MET) and water-soluble metabolites (WAT.MET) in sediment, overlying and interstitial water 
Data and statistical analysis. Fluxes of unmetabolized pyrene, organic- and water-soluble metabolites to overlying water and ${ }^{14} \mathrm{CO}_{2}$ production were estimated by linear regression of cumulative release data. The total production of ${ }^{14} \mathrm{CO}_{2}$ in microcosms was calculated as the sum of total amounts of ${ }^{14} \mathrm{CO}_{2}$ remaining in overlying water prior to extraction and trapped in $\mathrm{NaOH}$ during the experiment. ${ }^{14} \mathrm{CO}_{2}$ production in interstitial water was almost immeasurable in both microcosms with and without worms, and therefore not included in calculations of total ${ }^{14} \mathrm{CO}_{2}$ production. Differences in fluxes of pyrene and metabolites in microcosms with and without polychaetes were tested by performing Student's $t$-tests on pairs of regression coefficients (Zar 1984).

Time-dependent changes in amounts of pyrene and derived compounds in sediment, interstitial water and overlying water were also tested by linear regression. If no significant change in concentrations of pyrene or metabolites over time were observed in microcosms with or without polychaetes, an average value representing the entire experimental period was calculated and 2-sample $t$-test used to test differences with and without worms. In cases with a significant time-dependent change of pyrene or metabolites, differences were tested at the end of the experiment, again using a 2 -sample $t$-test.

Cumulative ${ }^{14} \mathrm{C}$-budgets were calculated over 43 and $42 \mathrm{~d}$ for microcosms with and without Arenicola marina or Nereis diversicolor, respectively, in order to estimate the importance of the 2 polychaetes for the turnover and fate of pyrene. All ${ }^{14} \mathrm{C}$-budgets were divided into the total amounts of water-soluble metabolites, organic-soluble metabolites, unmetabolized pyrene and ${ }^{14} \mathrm{CO}_{2}$ formed in sealed microcosms, although budgets for the $N$. diversicolor and A. marina experiments were calculated slightly differently as follows. As mentioned earlier, overlying water was sampled and analyzed from different microcosms at each time point during the $N$. diversicolor experiment. Sampling and analysis of interstitial water and sediment were made from the same microcosms with and without $N$. diversicolor sampled on Day 42. To estimate ${ }^{14} \mathrm{C}$-budgets over $42 \mathrm{~d}$ in the $\mathrm{N}$. diversicolor experiment, cumulative data were obtained by adding the average amount of water-soluble metabolites, organicsoluble metabolites, ${ }^{14} \mathrm{CO}_{2}$ and unmetabolized pyrene in the overlying water of replicate microcosms with and without $N$. diversicolor over $42 \mathrm{~d}$. Absolute standard deviation of total amount of water-soluble metabolites, organic-soluble metabolites, unmetabolized pyrene and ${ }^{14} \mathrm{CO}_{2}$ was calculated at Day 42 by propagating SD from each day of sampling (Eq. 1).

$$
\mathrm{S}(\text { absolute })=\sqrt{\sum_{i=\text { Day } 5}^{\text {Day } 42}\left(\mathrm{~S}^{2}\right)}
$$

Differences in total amount of unmetabolized pyrene, ${ }^{14} \mathrm{CO}_{2}$, water- and organic-soluble metabolites in microcosms with and without Nereis diversicolor were tested by 2 -sample $t$-test based on absolute errors.

In contrast to the Nereis diversicolor experiment, all sampling and analysis of overlying water during the Arenicola marina experiment was done for the same microcosms; all of which were terminated for analysis of sediment and interstitial water at Day 43. Total amounts of unmetabolized pyrene, water-soluble metabolites, organic-soluble metabolites and ${ }^{14} \mathrm{CO}_{2}$ released to the overlying water or remaining in the interstitial water and sediment were calculated in each microcosm with or without A. marina, and the effect of $A$. marina tested using the 2 -sample $t$-test.

\section{RESULTS}

Mortality was approximately $10 \%$ for Arenicola marina, but no decrease in mean weight of surviving worms was observed (data not shown). Feeding rates for A. marina decreased in a linear manner over $48 \mathrm{~d}$ (data not shown), with feces production being 2 -fold higher at Day $9\left(0.31 \pm 0.03 \mathrm{~g} \mathrm{~h}^{-1}\right)$ compared to Day 48 $\left(0.17 \pm 0.04 \mathrm{~g} \mathrm{~h}^{-1}\right)$. No mortality or weight loss was observed for Nereis diversicolor. Worm shafts were observed at all depths of the sediment cores in microcosms with $N$. diversicolor or A. marina suggesting, theoretically at least, that the polychaetes had the ability to fully rework all the sediment in the microcosms.

\section{${ }^{14} \mathrm{C}$-budgets in microcosms}

Cumulative ${ }^{14} \mathrm{C}$-budgets were calculated over 42 to $43 \mathrm{~d}$ in order to compare the amounts of unmetabolized pyrene, metabolites (water- and organic-soluble) and ${ }^{14} \mathrm{CO}_{2}$ in microcosms with and without polychaetes. The total amount of unmetabolized pyrene remaining was significantly greater in microcosms without worms compared to microcosms with Arenicola marina ( $\mathrm{p} \leq$ $0.01)$ or Nereis diversicolor $(p \leq 0.02)$, with the greatest reduction in unmetabolized pyrene observed in microcosms with $N$. diversicolor (Fig. 2). After $43 \mathrm{~d}$, the presence of $A$. marina had significantly increased the amount of ${ }^{14} \mathrm{CO}_{2}(\mathrm{p} \leq 0.007)$ as well as water-soluble $(p \leq 0.001)$ and organic-soluble metabolites ( $p \leq 0.001)$ in microcosms compared to microcosms without worms. Additionally, a great increase in total amount of watersoluble metabolites $(\mathrm{p} \leq 0.02)$ was observed in microcosms with $N$. diversicolor compared to those without; although total ${ }^{14} \mathrm{CO}_{2}$ production over $42 \mathrm{~d}$ was significantly higher in microcosms without $N$. diversicolor $(\mathrm{p} \leq$ $0.001)$. No statistically significant differences in the total 


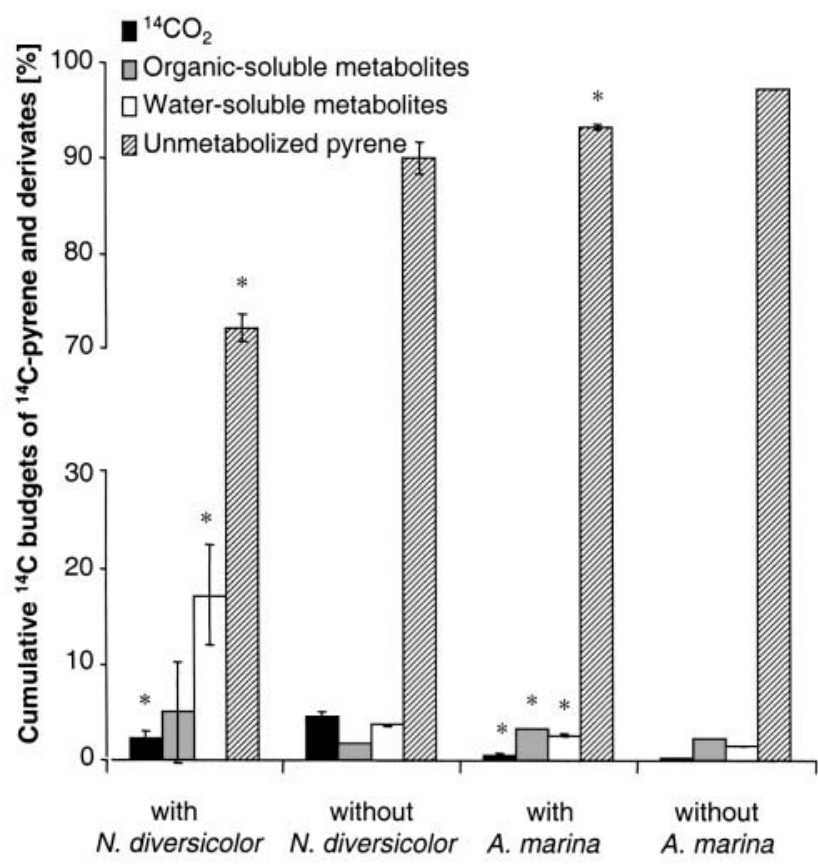

Fig. 2. Cumulative ${ }^{14} \mathrm{C}$-budgets of ${ }^{14} \mathrm{C}$-pyrene and ${ }^{14} \mathrm{C}$-pyrene derivatives after 42 and $43 \mathrm{~d}$ in microcosms with and without Nereis diversicolor (mean \pm propagated SE, $\mathrm{n}=3$ to 4 ) or Arenicola marina (mean $\pm \mathrm{SE}, \mathrm{n}=6$ ), respectively. "Significant difference in \% amounts of ${ }^{14} \mathrm{CO}_{2}$, water-soluble metabolites, organic-soluble metabolites or unmetabolized pyrene among microcosms with A. marina or $N$. diversicolor compared to microcosms without worms (2-sample $t$-test, $\mathrm{p} \leq 0.05$ )

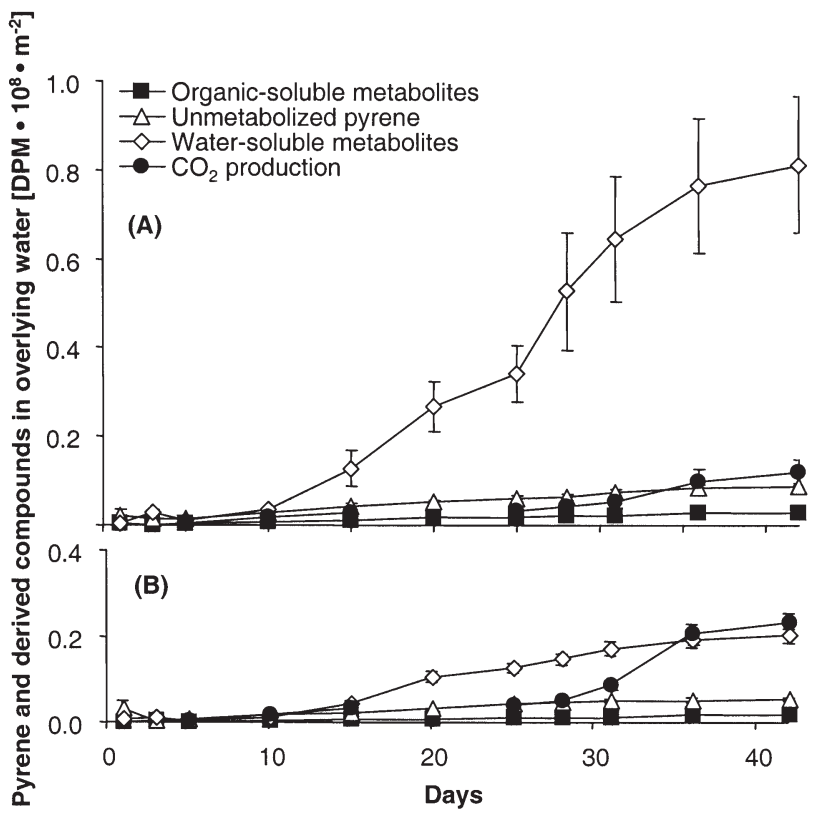

Fig. $3 .{ }^{14} \mathrm{C}$-pyrene, ${ }^{14} \mathrm{C}$-pyrene metabolites and ${ }^{14} \mathrm{CO}_{2}$ in overlying water over a period of $42 \mathrm{~d}$ from microcosms (A) with and (B) without Nereis diversicolor (cumulative presentation). Mean $\pm \mathrm{SE}, \mathrm{n}=3$ to 4 amounts of ${ }^{14} \mathrm{C}$-pyrene plus ${ }^{14} \mathrm{C}$-pyrene-derived compounds were found when comparing microcosms with and without polychaetes (data not shown, $\mathrm{p} \leq 0.57$ and 0.5 for A. marina and $N$. diversicolor, respectively). This indicates conservation of ${ }^{14} \mathrm{C}$-pyrene compounds in closed microcosms, especially ${ }^{14} \mathrm{CO}_{2}$.

\section{Pyrene and derived compounds in overlying water}

\section{Nereis diversicolor}

The release of pyrene and pyrene-derived radioactivity from sediment to overlying water differed substantially between microcosms with and without Nereis diversicolor (Fig. 3). The presence of $N$. diversicolor significantly enhanced the flux of unmetabolized pyrene and water- and organic-soluble metabolites into overlying water (Table 1). The release of water-soluble metabolites was the major removal path of pyrene and derived compounds with $N$. diversicolor present. In contrast to total ${ }^{14} \mathrm{CO}_{2}$ production at Day 42 (Fig. 2), the rate of ${ }^{14} \mathrm{CO}_{2}$ production to overlying water was slightly, but not significantly, lower in microcosms with than without $N$. diversicolor during the experiment. The rate of ${ }^{14} \mathrm{CO}_{2}$ production increased significantly ( $p \leq 0.05$ ) after $25 \mathrm{~d}$ in both microcosms with and without worms, and therefore ${ }^{14} \mathrm{CO}_{2}$ production was calculated for the periods from

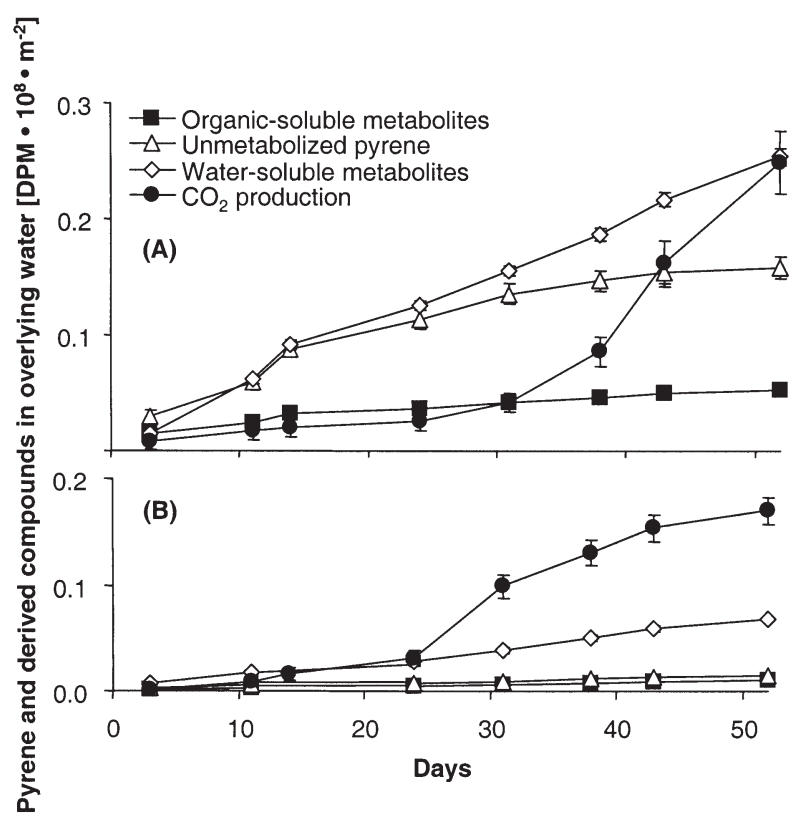

Fig. $4 .{ }^{14} \mathrm{C}$-pyrene, ${ }^{14} \mathrm{C}$-pyrene metabolites and ${ }^{14} \mathrm{CO}_{2}$ in overlying water over a period of $52 \mathrm{~d}$ from microcosms (A) with and (B) without Arenicola marina (cumulative presentation). Mean $\pm \mathrm{SE}, \mathrm{n}=6$ 
Days 5 to 25 and 28 to 42 , respectively (Table 1 ). The release of ${ }^{14} \mathrm{CO}_{2}$ was described as 2 linear relations, even though a better description may have been obtained using more complex modeling. However, linear regression was found suitable for the estimation of ${ }^{14} \mathrm{CO}_{2}$ production rates in this experiment. By summing the calculated fluxes of unmetabolized pyrene and metabolites, it can be estimated that the presence of $N$. diversicolor increased the loss of pyrene and derived compounds from the sediment by a factor of 3 .

\section{Arenicola marina}

The fluxes of water- and organic-soluble metabolites as well as unmetabolized pyrene to overlying water were all significantly higher in microcosms inhabited by Arenicola marina than without lugworms (Fig. 4, Table 2). Loss of pyrene out of the sediment and production of water-soluble metabolites were the major routes for the transfer of pyrene and derived compounds to overlying water in microcosms inhabited by A. marina. Production of ${ }^{14} \mathrm{CO}_{2}$ was a significant pathway for loss of pyrene from the sediment after $31 \mathrm{~d}$, however, especially in microcosms with A. marina. The flux of unmetabolized pyrene decreased after $32 \mathrm{~d}$ in the presence of A. marina but not in the absence of worms, while ${ }^{14} \mathrm{CO}_{2}$ production in microcosms with worms increased extensively after Day 32. Production of ${ }^{14} \mathrm{CO}_{2}$ increased in microcosms without worms as well, but might be close to reaching a maximum level by the end of the experiment (Fig. 4B). Similar to the Nereis diversicolor experiment, the presence of $A$. marina increased the loss of unmetabolized pyrene and derived compounds from the sediment by a factor of 3 (summation of calculated fluxes in Table 2).

\section{Pyrene and derived compounds in interstitial water}

\section{Nereis diversicolor}

Unmetabolized pyrene was the main ${ }^{14} \mathrm{C}$-labeled compound found in inter- stitial water in microcosms with and without Nereis diversicolor (Fig. 5, Table 3). Amounts of unmetabolized pyrene and organic-soluble metabolites in interstitial water did not change during the course of the experiment in microcosms with and without $N$. diversicolor, although fluctuations occurred. No significant differences were found between the average pools of unmetabolized pyrene and organic-soluble metabolites when microcosms with and without $N$. diversicolor were compared (Table 3). Water-soluble metabolites increased significantly over time in microcosms without worms ( $\mathrm{p} \leq 0.025)$, but not in microcosms

Table 1. Fluxes of unmetabolized ${ }^{14} \mathrm{C}$-pyrene and water- and organic-soluble ${ }^{14} \mathrm{C}$-pyrene metabolites from sediment to overlying water and production of ${ }^{14} \mathrm{CO}_{2}\left[\mathrm{dpm} \mathrm{m} \mathrm{m}^{-2} \mathrm{~d}^{-1}\right]$. Fluxes were determined by linear regression of data in Fig. 3 from Days 5 to 42 , assuming linear relations. ${ }^{14} \mathrm{CO}_{2}$ production was calculated from Days 5 to 25 and 28 to 42, respectively (see text). The coefficient of determination $\left(\mathrm{R}^{2}\right)$ for each regression is shown in parentheses. Results from $t$-test for differences in fluxes with and without Nereis diversicolor are indicated either as non-significant (ns) or with a p-value for significant differences

\begin{tabular}{|c|c|c|c|}
\hline$\left[\mathrm{dpm} \mathrm{m} \mathrm{m}^{-2} \mathrm{~d}^{-1}\right]$ & $\begin{array}{l}\text { With } N \text {. } \\
\text { diversicolor }\end{array}$ & $\begin{array}{l}\text { Without } N \text {. } \\
\text { diversicolor }\end{array}$ & $\mathrm{p}$-value \\
\hline $\begin{array}{l}\text { Water-soluble } \\
\text { metabolites }\end{array}$ & $2.0 \times 10^{6}(0.96)$ & $6.0 \times 10^{5}(0.96)$ & $\leq 0.001$ \\
\hline $\begin{array}{l}\text { Organic-soluble } \\
\text { metabolites }\end{array}$ & $0.8 \times 10^{5}(0.98)$ & $0.5 \times 10^{5}(0.97)$ & $\leq 0.001$ \\
\hline $\begin{array}{l}\text { Unmetabolized } \\
\text { pyrene }\end{array}$ & $2.0 \times 10^{5}(0.93)$ & $1.4 \times 10^{5}(0.93)$ & $\leq 0.001$ \\
\hline${ }^{14} \mathrm{CO}_{2}$ Days 5 to 25 & $1.5 \times 10^{5}(0.87)$ & $1.8 \times 10^{5}(0.91)$ & ns \\
\hline${ }^{14} \mathrm{CO}_{2}$ Days 28 to 42 & $5.9 \times 10^{5}(0.96)$ & $1.4 \times 10^{6}(0.91)$ & ns \\
\hline
\end{tabular}

Table 2. Fluxes of unmetabolized ${ }^{14} \mathrm{C}$-pyrene and water- and organic-soluble ${ }^{14} \mathrm{C}$-pyrene metabolites from sediment to overlying water and production of ${ }^{14} \mathrm{CO}_{2}\left[\mathrm{dpm} \mathrm{m} \mathrm{m}^{-2} \mathrm{~d}^{-1}\right]$. Fluxes were determined by linear regression of data in Fig. 4, from Days 3 to 52, assuming linear relations. ${ }^{14} \mathrm{CO}_{2}$ production and flux of unmetabolized pyrene were calculated from Days 3 to 24 and 32 to 52, respectively (see text). The coefficient of determination $\left(\mathrm{R}^{2}\right)$ for each regression is shown in parentheses. Results from $t$-test for differences in fluxes with and without Arenicola marina are indicated with a p-value for significant differences

\begin{tabular}{|lccc|}
\hline [dpm $\left.{ }^{-2} \mathrm{~d}^{-1}\right]$ & With A. marina & Without A. marina & p-value \\
\hline $\begin{array}{l}\text { Water-soluble } \\
\text { metabolites }\end{array}$ & $4.8 \times 10^{5}(0.99)$ & $1.3 \times 10^{5}(0.99)$ & $\leq 0.001$ \\
$\begin{array}{l}\text { Organic-soluble } \\
\text { metabolites }\end{array}$ & $0.7 \times 10^{5}(0.96)$ & $0.2 \times 10^{5}(0.98)$ & $\leq 0.001$ \\
$\begin{array}{l}\text { Unmetabolized pyrene } \\
\text { Days 3 to 24 }\end{array}$ & $4.1 \times 10^{5}(0.96)$ & $0.2 \times 10^{5}(0.98)$ & $\leq 0.001$ \\
$\begin{array}{l}\text { Unmetabolized pyrene } \\
\text { Days 32 to 52 }\end{array}$ & $1.2 \times 10^{5}(0,93)$ & $0.2 \times 10^{5}(0.98)$ & $\leq 0.001$ \\
$\begin{array}{l}{ }^{14} \mathrm{CO}_{2} \text { Days 3 to 24 } \\
{ }^{14} \mathrm{CO}_{2} \text { Days 31 to 52 }\end{array}$ & $0.8 \times 10^{5}(0.96)$ & $1.4 \times 10^{5}(0.97)$ & $\leq 0.05$ \\
& $1.0 \times 10^{6}(0.98)$ & $3.4 \times 10^{5}(0.94)$ & $\leq 0.005$ \\
\hline
\end{tabular}




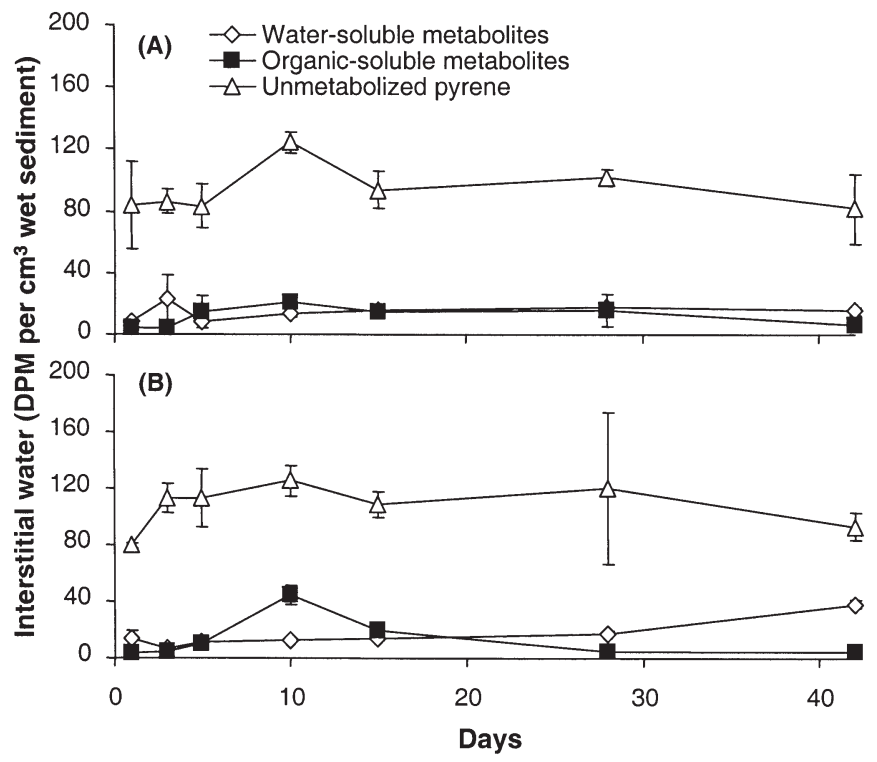

Fig. 5. ${ }^{14} \mathrm{C}$-pyrene and ${ }^{14} \mathrm{C}$-pyrene metabolites in interstitial water over a period of $42 \mathrm{~d}$ from microcosms (A) with and (B) without Nereis diversicolor. Radioactivity is calculated as dpm per $\mathrm{cm}^{3}$ wet sediment $(\varphi=0.34 \pm 0.01, \mathrm{n}=4)$. Mean $\pm \mathrm{SE}$, $\mathrm{n}=4$

inhabited by $N$. diversicolor. At Day 42, the amount of water-soluble metabolites was significantly higher $(p \leq 0.01)$ in microcosms without worms. The sum of metabolites in microcosms with and without $N$. diversicolor accounted for ca. 22 and $31 \%$ of the total amount of pyrene and derived compounds in interstitial water, respectively.

\section{Arenicola marina}

The amount of unmetabolized pyrene in interstitial water decreased significantly ( $p \leq 0.05)$ during the $52 \mathrm{~d}$ the experiment lasted in microcosms with Arenicola marina (Fig. 6, Table 3). Even though the amount of unmetabolized pyrene in microcosms without lugworms appeared to decrease as well, this was not statistically significant $(p \leq 0.25)$. The amounts of waterand organic-soluble metabolites were constant over

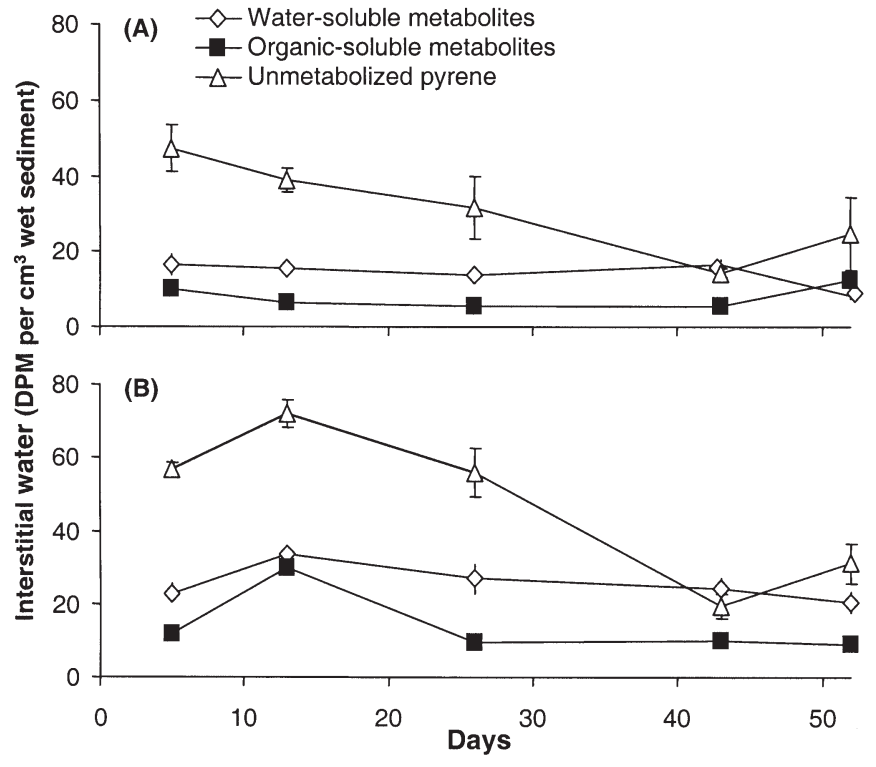

Fig. $6 .{ }^{14} \mathrm{C}$-pyrene and ${ }^{14} \mathrm{C}$-pyrene metabolites in interstitial water over a period of $52 \mathrm{~d}$ from microcosms (A) with and (B) without Arenicola marina. Radioactivity is calculated as $\mathrm{dpm}$ per $\mathrm{cm}^{3}$ wet sediment $(\varphi=0.34 \pm 0.01, \mathrm{n}=4)$. Mean $\pm \mathrm{SE}$, $\mathrm{n}=6$

time both in the presence and absence of worms (Fig. 6, Table 3). However, the average concentrations of water-soluble metabolites were significantly higher in microcosms without worms compared to microcosms with A. marina ( $\mathrm{p} \leq 0.003$ ). Pyrene metabolites accounted for a much higher proportion (40 to $60 \%$ ) of the total amount of pyrene and derived compounds in microcosms with and without $A$. marina than in the experiment with Nereis diversicolor (Table 3).

\section{Pyrene and derived compounds in sediment}

\section{Nereis diversicolor}

The concentration of unmetabolized pyrene in the sediment decreased significantly ( $\mathrm{p} \leq 0.01$ ) over time in microcosms with Nereis diversicolor (Fig. 7A,

Table 3. Distribution of ${ }^{14} \mathrm{C}$-pyrene and ${ }^{14} \mathrm{C}$-pyrene metabolites in interstitial water in microcosms with and without Nereis diversicolor or Arenicola marina. Radioactivity is calculated as $\mathrm{dpm} \mathrm{cm}^{-3}$ wet sediment. ${ }^{*}$ Significant linear trend over time. ${ }^{\mathrm{a}} \mathrm{Concen}-$ trations calculated at the end of the experiment (mean $\pm \mathrm{SE}, \mathrm{n}=3$ to 6 ); unmarked values are average concentrations during the entire experiment (mean $\pm \mathrm{SE}, \mathrm{n}=24$ to 28 ). ${ }^{\mathrm{b}}$ Significant differences between concentrations in microcosms with and without polychaetes (2-sample $t$-test, $\mathrm{p} \leq 0.05)$

\begin{tabular}{|c|c|c|c|c|}
\hline dpm $\mathrm{cm}^{-3}$ wet sediment & With $N$. diversicolor & Without $N$. diversicolor & With A. marina & Without A. marina \\
\hline Water-soluble metabolites & $15.2 \pm 2.0^{\mathrm{a}, \mathrm{b}}$ & $37.5 \pm 3.8^{*, a, b}$ & $13.9 \pm 1.6^{\mathrm{b}}$ & $25.2 \pm 2.3^{b}$ \\
\hline Organic-soluble metabolites & $11.4 \pm 2.4$ & $12.7 \pm 5.6$ & $7.9 \pm 1.4$ & $13.8 \pm 3.9$ \\
\hline Unmetabolized pyrene & $92.0 \pm 5.7$ & $105.9 \pm 5.9$ & $30.8 \pm 5.6^{*, \mathrm{a}}$ & $21.0 \pm 9.4^{\mathrm{a}}$ \\
\hline
\end{tabular}




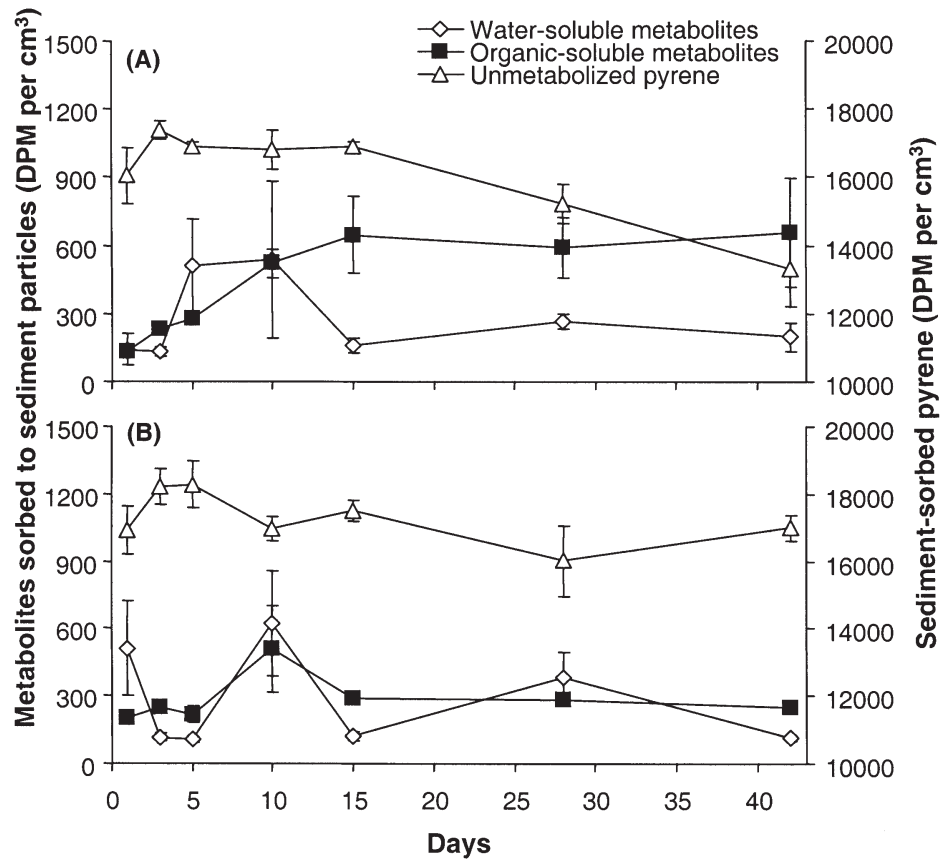

Fig. 7. ${ }^{14} \mathrm{C}$-pyrene and ${ }^{14} \mathrm{C}$-pyrene metabolites in sediment over a period of 42 d. (A) Sediment inhabited by Nereis diversicolor and (B) sediment without $N$. diversicolor. Radioactivity is calculated as dpm per $\mathrm{cm}^{3}$ wet sediment $(\varphi=0.34 \pm 0.01, \mathrm{n}=4)$. Mean $\pm \mathrm{SE}, \mathrm{n}=4$

The concentration of water-soluble pyrene metabolites fluctuated throughout the experiment in both microcosms with and without worms, but no significant time-dependent changes or differences in concentrations were detected.

\section{Arenicola marina}

The presence of Arenicola marina did lead to measurable changes in the amounts of watersoluble metabolites and unmetabolized pyrene in sediments (Fig. 8, Table 4). In contrast to sediment inhabited by Nereis diversicolor, no decrease in the amount of unmetabolized pyrene was observed in microcosms with and without A. marina. In fact, the data in Fig. 8 suggest a slight, although not significant, increase in the concentration of pyrene, but this must be a result of inhomogeneous mixing of the sediment or extraction errors. Furthermore, no significant differences in the average concentration of unmetabolized pyrene were observed in sediments with and without $A$. marina. The amount of organic-soluble metabolites in microcosms inhabited by $A$. marina

Table 4). After $42 \mathrm{~d}$, only $75 \%$ of the pyrene originally added to the sediment remained in microcosms inhabited by $N$. diversicolor. There was a much slower decrease in the concentration of pyrene in cores without $N$. diversicolor (rate not significantly different from 0). At Day 42, the concentration of unmetabolized pyrene was significantly higher $(p \leq 0.01)$ in microcosms without worms compared to microcosms with $N$. diversicolor. The amount of organicsoluble pyrene metabolites increased significantly in microcosms with $N$. diversicolor until Day 15 and then stabilized at a constant level, while no change was observed in microcosms without worms. However, the concentration of organic-soluble metabolites in microcosms with and without $N$. diversicolor did not differ significantly at the end of the experiment (Table 4). increased significantly ( $\leq 0.05$ ) over time and was significantly higher $(\mathrm{p} \leq 0.01)$ in microcosms with lugworms compared to microcosms without $A$. marina at the end of the experiment.

\section{DISCUSSION}

Both Arenicola marina and Nereis diversicolor enhanced removal of ${ }^{14} \mathrm{C}$-pyrene from the sediment, although the mechanisms and forms of pyrene-derived compounds involved in these fluxes differed. Overall pyrene metabolism in sediment was stimulated by both polychaetes; however, extensive bioturbation of the sediment resulted in flux of unmetabolized pyrene being the major removal pathway in the presence of

Table 4. Distribution of ${ }^{14} \mathrm{C}$-pyrene and ${ }^{14} \mathrm{C}$-pyrene metabolites bound to sediment particles in microcosms with and without Nereis diversicolor or Arenicola marina. Radioactivity is calculated as dpm $\mathrm{cm}^{-3}$ wet sediment. *Significant linear trend over time. ${ }^{a}$ Concentrations were calculated at the end of the experiment (mean $\pm \mathrm{SE}, \mathrm{n}=3$ to 6 ); unmarked values are average

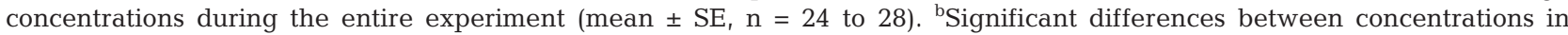
microcosms with and without polychaetes (2-sample $t$-test; $\mathrm{p} \leq 0.05)$

\begin{tabular}{|c|c|c|c|c|}
\hline $\mathrm{dpm} \mathrm{cm}^{-3}$ wet sediment & With $N$. diversicolor & Without $N$. diversicolor & With A. marina & Without A. marina \\
\hline Water-soluble metabolites & $277.1 \pm 65.9$ & $281.3 \pm 83.6$ & $220.3 \pm 41.2$ & $163.6 \pm 16.3$ \\
\hline Organic-soluble metabolites & $654.7 \pm 204.7^{*, \mathrm{a}}$ & $204.6 \pm 7.8^{\mathrm{a}}$ & $481.1 \pm 50.6^{*, \mathrm{a}, \mathrm{b}}$ & $384.1 \pm 24.9^{\mathrm{a}, \mathrm{b}}$ \\
\hline Unmetabolized pyrene & $13306 \pm 1102^{*, a, b}$ & $16998 \pm 379^{\mathrm{a}, \mathrm{b}}$ & $15569 \pm 586$ & $15806 \pm 721$ \\
\hline
\end{tabular}




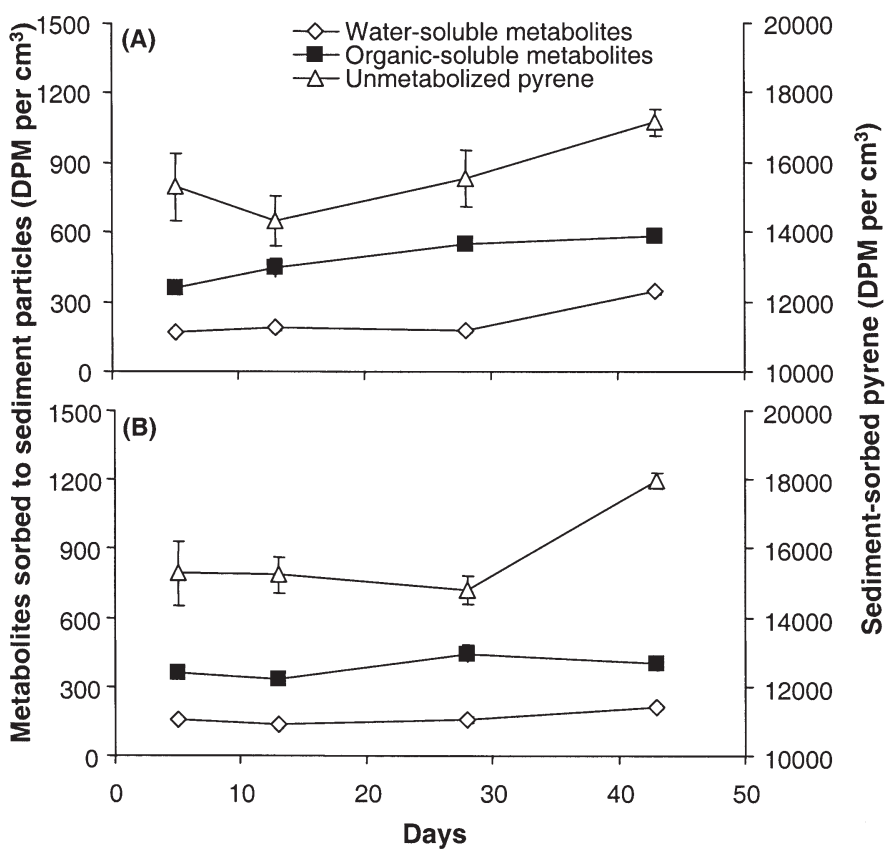

Fig. $8 .{ }^{14} \mathrm{C}$-pyrene and ${ }^{14} \mathrm{C}$-pyrene metabolites in sediment over a period of $42 \mathrm{~d}$. (A) Sediment inhabited by Arenicola marina and (B) sediment without A. marina. Radioactivity is calculated as dpm per $\mathrm{cm}^{3}$ wet sediment $(\varphi=0.34 \pm 0.01, \mathrm{n}=4)$. Mean $\pm \mathrm{SE}, \mathrm{n}=4$

A. marina. In contrast, flux of water-soluble pyrene metabolites was the major removal pathway of pyrene in sediment inhabited by $N$. diversicolor, suggesting direct metabolism by the worm itself. This metabolism led to a significant decrease of sediment-sorbed pyrene over time in microcosms inhabited by $N$. diversicolor. No significant decrease was detected in sedimentsorbed pyrene over time in the presence of lugworms, but this may be due to the necessity of using significantly greater amounts of sediment in microcosms with A. marina compared to $N$. diversicolor. The overall fluxes of pyrene and pyrene metabolites to overlying water were increased by 42 and $35 \%$ in the presence of A. marina and $N$. diversicolor, respectively, indicating that both polychaetes affected the fate of sediment-bound pyrene. Also, the calculated ${ }^{14} \mathrm{C}$-budgets showed that the presence of $A$. marina or $N$. diversicolor significantly increased the removal and metabolism of ${ }^{14} \mathrm{C}$-pyrene in microcosms over the experimental timescale of 42 to $43 \mathrm{~d}$, compared to microcosms without worms.

\section{Pyrene metabolism: microorganisms versus polychaetes}

The significantly increased production of watersoluble metabolites after 42 to $43 \mathrm{~d}$ in microcosms inhabited by either polychaete species indicates either direct metabolism of pyrene by Nereis diversicolor and Arenicola marina, enhanced metabolism by sediment microbiota, or both. In this study, microbial degradation (expressed as cumulative ${ }^{14} \mathrm{CO}_{2}$ production after $42 \mathrm{~d}$ ) was significantly depressed by the presence of $N$. diversicolor. This indicates that the increase in flux and total production of water-soluble metabolites in microcosms with $N$. diversicolor was a consequence of metabolic activity by the polychaete itself. In contrast, cumulative ${ }^{14} \mathrm{CO}_{2}$ production after $43 \mathrm{~d}$ was significantly enhanced by the presence of $A$. marina, suggesting that the lugworm stimulated microbial metabolism of pyrene through bioturbation. Stimulation of the pyrene-degrading microbial community by A. marina, however, occurred only during the last $15 \mathrm{~d}$ of the experiment, where a greater flux rate of ${ }^{14} \mathrm{CO}_{2}$ to overlying water was observed in microcosms with than without worms. The extensive increase in ${ }^{14} \mathrm{CO}_{2}$ production after $32 \mathrm{~d}$ in the presence of $A$. marina was, however, not paralleled by an increase in the flux rate of water-soluble metabolites to overlying water, which remained constant throughout the experimental period. Accordingly, the increased flux of water-soluble metabolites to overlying water throughout the experiment was not directly related to microbial metabolism but rather to metabolic activity of A. marina. The importance of polychaete metabolism relative to microbial metabolism has previously been shown by McElroy et al. (1990), who exposed $N$. virens to benz[a]antrachene. Furthermore, N. diversicolor and the related species $N$. virens metabolize PAHs most likely by CYP enzymes followed by further conjugation via Phase 2 reactions and excretion (Lee \& Singer 1980, McElroy 1985, McElroy et al. 1990, Driscoll \& McElroy 1996). So far, CYP enzyme activity has not been detected in A. marina or other Arenicolids, even though A. pacifica produced metabolites in tissues during in vivo exposure to benzo[a]pyrene (Augenfeld \& Anderson 1982, Weston 1990). We recently observed increased amounts of water-soluble metabolites in tissues of $A$. marina with increasing exposure time and, in fact, concentrations were even higher than in tissues of $N$. diversicolor (Christensen et al. 2002). Thus, there is good evidence that both these polychaete species actively metabolize PAHs and that polychaete metabolism was responsible for most of the pyrene removed in these experiments.

\section{Impact of polychaetes on microbial degradation}

The initial ca. $30 \mathrm{~d}$ lag phase in ${ }^{14} \mathrm{CO}_{2}$ production observed in this and other studies (Heitkamp \& Cerniglia 
1987, Heitkamp et al. 1988) suggests that a selection or adaptation of pyrene-degrading bacteria must occur over time. In this study, bacterial metabolism of pyrene, measured as flux of ${ }^{14} \mathrm{CO}_{2}$ to overlying water, was depressed by Arenicola marina and Nereis diversicolor during this lag phase. Although only speculative, it is possible that bacterial grazing by both polychaetes suppressed the selective or adaptive change in the microbial community, thereby decreasing the ${ }^{14} \mathrm{CO}_{2}$ production in the early experimental stage. After $32 \mathrm{~d},{ }^{14} \mathrm{CO}_{2}$ production increased significantly in the presence of $A$. marina compared to microcosms without worms, resulting in an overall stimulation of pyrene-degrading bacteria after $43 \mathrm{~d}$. In contrast, total ${ }^{14} \mathrm{CO}_{2}$ production at Day 42 was significantly higher in the absence of $N$. diversicolor. This is surprising as $N$. diversicolor has previously been shown to stimulate overall bacterial metabolism in sediments, although to a lesser extent than A. marina (Andersen \& Kristensen 1988, Banta et al. 1999). Furthermore, the related polychaetes $N$. virens and Capitella capitata are known to enhance microbial degradation of PAHs like benz[a]anthracene (Gardner et al. 1979, McElroy et al. 1990) and antrachene (Bauer et al. 1988), respectively. However, the significant decrease in the bulk sediment concentration of unmetabolized pyrene by $25 \%$ during the $42 \mathrm{~d}$ experiment by $N$. diversicolor may explain the lack of stimulation of pyrene-degrading bacteria as discussed below.

As metabolism to primarily water-soluble metabolites by Nereis diversicolor occurs in animal tissues, removal of pyrene from feeding activity, ventilation and diffusion from interstitial water may be very high in the proximity of the animal. Thus, depletion of pyrene from the burrow wall sediments during the early experimental period may explain the lack of increased ${ }^{14} \mathrm{CO}_{2}$ production in the presence of $N$. diversicolor. We suggest that any stimulation in microbial metabolism of ${ }^{14} \mathrm{C}$-pyrene due to $N$. diversicolor was offset by diminishing concentrations of ${ }^{14} \mathrm{C}$-pyrene in burrow wall sediments over time.

In contrast to this experiment, McElroy et al. (1990) found that the related species Nereis virens stimulated mineralization of benz(a)anthracene by a factor of 2.4 ; however, they did not observe a significant decrease in bulk sediment concentrations. These contradicting results may stress the importance of measuring metabolism, flushing and mineralization in burrow wall sediment inhabited by Nereid species in order to better understand the effect of these polychaetes on microbial PAH metabolism.

In this study, production of ${ }^{14} \mathrm{CO}_{2}$ from pyrene, indicative of bacterial metabolism, was a minor removal pathway in all microcosms, both with and without polychaetes. However, bacterial metabolism of pyrene may not be adequately described by ${ }^{14} \mathrm{CO}_{2}$ production. A number of partially characterized pathways of bacterial pyrene metabolism lead to end products that contain all or at least 2 of the ${ }^{14} \mathrm{C}$-labeled carbons positions in $\left[{ }^{14} \mathrm{C}-4,5,9,10\right]$-pyrene (Cerniglia 1992, Rehmann et al. 1998, Kanaly \& Harayama 2000). These primary end products may be substrates for further microbial metabolism. Accordingly, liberation of ${ }^{14} \mathrm{CO}_{2}$ in the present study is indicative of bacterial $\left[{ }^{14} \mathrm{C}-4,5,9,10\right]$ pyrene metabolism but not necessarily complete pyrene mineralization. It may be possible that the bacterial community, especially in the lag phases, is dominated by species able to metabolize but not able to extensively degrade pyrene to ${ }^{14} \mathrm{CO}_{2}$. Poor degradation capacity by bacterial species and metabolism in fungus or algae may result in a build-up of metabolites in overlying water, sediment or interstitial water. A build-up of organic- and water-soluble dead-end products of benz[a]antrachene has been detected in sediments with a natural mixed microbial community (Hinga \& Pilson 1987).

In this experiment, no increase in metabolites in interstitial water over time was found in microcosms with or without Arenicola marina, or in the presence of Nereis diversicolor; in contrast, the amount of watersoluble metabolites increased significantly in microcosms without $N$. diversicolor. The latter is possibly a result of metabolism by fungi or bacteria which were not able to fully degrade pyrene to $\mathrm{CO}_{2}$. Furthermore, water- and organic-soluble metabolites adsorbed to sediment particles were observed in all microcosms. Sediment-sorbed organic-soluble metabolites increased in microcosms with worms but not without worms, even though ${ }^{14} \mathrm{CO}_{2}$ data indicated similar or higher bacterial activity in microcosms without than with worms, at least until Day 32. This difference in pyrene metabolism between microcosms with and without worms suggests differences in microbial communities and degradation pathways in non-bioturbated surface sediments and sediments associated with polychaete burrows (Chung \& King 1999). The apparent buildup of organic-soluble metabolites in sediments with worms is indicative of increased metabolism of pyrene by a microbial community not able to completely mineralize pyrene.

\section{Flushing effects by the polychaetes}

Given that a major removal route of pyrene from sediments was the transfer of pyrene and pyrenederived compounds (metabolites and ${ }^{14} \mathrm{CO}_{2}$ ) to the overlying water, it is not surprising that the main differences between microcosms with the 2 polychaete species was seen in the overlying water. The faster 
removal of parent pyrene and organic-soluble metabolites in the presence of Arenicola marina is due to its mode of bioturbation. Ventilation of A. marina's J-shaped tube results in flushing of interstitial water through the feeding-funnel, increasing the rate of exchange of water between sediment interstitial water and overlying water 10- to 20-fold (Rasmussen et al. 1998, Banta et al. 1999). Furthermore, this exchange is caused by advection transport (Timmermann et al. 2002), in contrast to enhanced diffusive transport, as is the case with Nereis diversicolor. $N$. diversicolor irrigates more extensively (250 to $700 \mathrm{ml} \mathrm{g}^{-1} \mathrm{~h}^{-1}$ ) (Kristensen 1983) than A. marina (10 to $60 \mathrm{ml} \mathrm{g}^{-1} \mathrm{~h}^{-1}$ ) (Rasmussen et al. 1998), but the water is pumped directly through the U-shaped tube, resulting in limited flushing of pyrene, especially from deeper sediment layers (Kristensen 1983, Banta et al. 1999). Gilbert et al. (1994) have previously shown that presence of $N$. diversicolor increases removal of oil compounds from sediment to the overlying water by 24 to $59 \%$, which is in agreement with a $30 \%$ increase in flux of unmetabolized pyrene observed in this study. Increased flux of unmetabolized pyrene to overlying water in the presence of $N$. diversicolor was not reflected in the average interstitial water concentrations of unmetabolized pyrene and metabolites in this study. However, flushing by $N$. diversicolor is most intensive in the upper sediment layers (Kristensen 1983, Banta et al. 1999), and a decrease in interstitial water distribution of pyrene and metabolites in this region was probably blurred by analyzing sediment from the entire microcosm as 1 pool.

The amount of unmetabolized pyrene in interstitial water decreased significantly over time in microcosms inhabited by Arenicola marina. Furthermore, a significantly lower average amount of water-soluble metabolites was observed in microcosms with A. marina, which could indicate higher flushing of interstitial water by $A$. marina. Hüttel (1990) and Banta et al. (1999) showed that $A$. marina was capable of flushing dissolved compounds and metabolites to great depths in the sediment. Kure (1997) showed that presence of A. marina increased the flux of fluoranthene from sediment to overlying water by a factor of 3 . A much higher flushing effect by A. marina was observed in the present study, where flux of unmetabolized pyrene increased by a factor of 20 .

\section{Timescale for pyrene removal}

The turnover of pyrene in sediments was significantly enhanced by Nereis diversicolor in this experiment. Half-lives of pyrene ranging from 238 to $630 \mathrm{~d}$ have been reported in natural sediment systems where removal resulted from microbial mineralization, with half-lives being greatest in pristine sediments (Heitkamp \& Cerniglia 1987). In this experiment, the halflife of pyrene in the sediment was reduced by the presence of $N$. diversicolor from ca. 277 to $99 \mathrm{~d}$. Turnover of PAHs like pyrene might be even greater under natural conditions, where $N$. diversicolor may occur in densities 10 times higher than the 471 worms $\mathrm{m}^{-2}$ used in this study. The presence of Capitella capitata has similarly been shown to reduce the turnover time for benzo[a]pyrene, primarily due to metabolism by the polychaete itself (Gardner et al. 1979, Lee et al. 1979). In contrast, a significant reduction in the bulk concentration of sediment-bound pyrene was not observed in microcosms with Arenicola marina, despite the fact that the flux of pyrene and derived compounds out of the sediment was similar to, or even greater than, the one in the presence of $N$. diversicolor. Even though observed fluxes of pyrene and metabolites out of the sediment and calculated ${ }^{14} \mathrm{C}$-budgets suggest that $A$. marina actually reduces the turnover time of pyrene in sediments, the reduction is rather small due to the necessity of large amounts of sediment in lugworm microcosms. However, a significant reduction by $2.4 \%$ in the total load of unmetabolized ${ }^{14} \mathrm{C}$ pyrene in microcosms inhabited by $A$. marina compared to microcosms without lugworms over $43 \mathrm{~d}$ indicates a considerable effect in situ, even though this is difficult to detect experimentally.

Measured $\log \mathrm{K}_{\mathrm{oc}}$ for unmetabolized pyrene was $4.82 \pm 0.21$ and $4.82 \pm 0.29$ in microcosms with and without Arenicola marina, respectively. These values are within the range of measured and predicted $\log \mathrm{K}_{\mathrm{oc}}$ presented by Karickhoff (1981), indicating equilibrium partitioning of unmetabolized pyrene between sediment and water in this experiment and thus limited pyrene complexation to dissolved organic matter in the interstitial water. Complexation to dissolved organic matter would decrease the measured $\log \mathrm{K}_{\mathrm{oc}}$. As a result, the large amount of unmetabolized pyrene flushed to the overlying water by $A$. marinas bioturbating activity will either readily associate with suspended particulate matter and be deposited in the sediment again or be readsorbed to the sediment as overlying water is pumped through the lugworm burrow. Accordingly, bioturbation by A. marina has an extensive effect on the removal of hydrophobic pyrene and metabolites from the sediment, but this effect may only be temporary. Furthermore, the above redistribution mechanisms may substantially spread the area of contamination depending on hydrographic conditions.

Densities of Arenicola marina used in this experiment (185 worms $\mathrm{m}^{-2}$ ) were in the upper range of natural densities of small individuals $(0.6 \mathrm{~g})$, while the densities of Nereis diversicolor were rather low (471 
worms $\mathrm{m}^{-2}$ ). Accordingly, this study implies that the impact of A. marina on removal of PAHs such as pyrene in the coastal bioturbated zone areas may be less than $N$. diversicolor, due to differences in their natural densities. However, bioturbation by A. marina affects pyrene distribution in sediments to much greater depths than $N$. diversicolor.

\section{Experimental errors}

The fate of pyrene was affected differently by the presence of Arenicola marina and Nereis diversicolor. It was surprising, however, that microcosms without worms did not behave identically in the 2 experiments, even though sediments were contaminated with similar amounts of ${ }^{14} \mathrm{C}$-pyrene in both experiments. This difference may be due to the fact that the sediment was sampled in spring for the $N$. diversicolor experiment and in the autumn for the $A$. marina experiment. Evolution of ${ }^{14} \mathrm{CO}_{2}$ did not differ noticeably between controls suggesting similar activity of PAH-degrading bacteria, but differences in the amounts of pyrene and derived compounds found in overlying water, interstitial water and sediment were observed between controls. These differences were evident in the calculated pyrene budgets in microcosms without $A$. marina and $N$. diversicolor, where a larger fraction of watersoluble metabolites was found in microcosms containing sediment collected in the spring $(N$. diversicolor experiment). The organic matter content $(0.17 \%)$ and porosity $(0.34)$ in the sediment did not differ between the 2 sampling sessions, but measured $\log \mathrm{K}_{\mathrm{oc}}$ differed between them, being $4.50 \pm 0.07$ and $4.82 \pm 0.23$ in sediment collected in spring and autumn, respectively. Partitioning coefficients and adsorption of PAHs depend on the organic content in the sediment (Means et al. 1980), although other factors like origin, age and particle size of the organic material as well as DOM in the interstitial water may influence the affinity for PAHs in sediments having similar organic contents (Landrum et al. 1987, Landrum 1989, Evans et al. 1990). Furthermore, sediment sampled in the spring may have contained a larger population of microbes (unable to degrade pyrene to ${ }^{14} \mathrm{CO}_{2}$ ) or meiofauna surviving freezing, which could account for the higher metabolite formation.

Differences between the control groups without worms make it difficult to compare the results measured in microcosms with Arenicola marina and Nereis diversicolor directly, at least without taking into account differences in the sediments in the 2 experiments. However, interpretations of differences in pools and rates related to the fate of pyrene including its metabolism, due to the presence of either polychaete species, were based on comparisons with the appropriate control microcosm for each experiment. Thus, we have clearly demonstrated that both polychaete species significantly enhance the removal of PAHs such as pyrene from the sediments, although in different ways.

Acknowledgements. This work was funded by the Danish Environmental Research Programme, Center for Biological Processes in Contaminated Soil and Sediments.

\section{LITERATURE CITED}

Andersen FØ, Kristensen E (1988) The influence of macrofauna on estuarine benthic community metabolism: a microcosm study. Mar Biol 99:591-603

Augenfeld JM, Anderson JW (1982) The fate of polyaromatic hydrocarbons in an intertidal sediment exposure system: bioavailability to Macoma inquinata (mollusca:pelecypoda) and Abarenicola pacifica (annelida:polychaeta). Mar Environ Res 7:31-50

Banta GT, Holmer M, Jensen M, Kristensen E, Riley RG, Thomas BL (1999) Effects of two polychaete worms, Nereis diversicolor and Arenicola marina, on aerobic and anaerobic decomposition in a sandy marine sediment. Aquat Microb Ecol 19:189-204

Bauer JE, Kerr RP, Bautista MF, Decker CJ, Capone DG (1988) Stimulation of microbial activities and polycyclic aromatic hydrocarbon degradation in marine sediments inhabited by Capitella capitata. Mar Environ Res 25:63-84

Cerniglia CE (1992) Biodegradation of polycyclic aromatic hydrocarbons. Biodegradation 3:351-368

Christensen M, Andersen O, Banta GT (2002) Metabolism of pyrene by the polychaetes Nereis diversicolor and Arenicola marina. Aquat Toxicol 58:15-25

Chung WK, King GM (1999) Biogeochemical transformations and potential polyaromatic hydrocarbon degradation in macrofaunal burrow sediments. Aquat Microb Ecol 19: 285-295

Dankers N, Kühl H, Wolf WJ (1981) Invertebrates of the Wadden Sea. AA Balkema, Rotterdam

Delaune WH, Patrick JR, Casselmann ME (1981) Effects of sediment $\mathrm{pH}$ and redox conditions on degradation of benzo(a)pyrene. Mar Pollut Bull 12(7):251-253

Driscoll SK, McElroy AE (1996) Bioaccumulation and metabolism of benzo[a]pyrene in three species of polychaete worms. Environ Toxicol Chem 15(8):1401-1410

Evans KM, Gill RA, Robotham PWJ (1990) The PAH and organic content of sediment particle size fractions. Water Air Soil Pollut 51:13-31

Fauchald K, Jumars PA (1979) The diet of worms: a study of polychaete feeding. Oceanogr Mar Biol Annu Rev 17: 193-284

Gardner WS, Lee RF, Tenore KR, Smith LW (1979) Degradation of selected polycyclic aromatic hydrocarbons in coastal sediments: importance of microbes and polychaete worms. Water Air Soil Pollut 11:339-347

Garrigues P, Raoux C, Lemaire P, Mathieu A, Ribara D, Narbonne JF, Lafaurie M (1990) In situ correlations between polycyclic aromatic hydrocarbons (PAH) and PAH metabolising system activities in mussels and fish in the Mediterranean sea: preliminary results. Int J Environ Anal Chem 38:379-387

Gilbert F, Rivet L, Bertrand JC (1994) The in vitro influence of the burrowing polychaete Nereis diversicolor on the fate 
of petroleum hydrocarbons in marine sediments. Chemosphere 29:1-12

Gordon DC, Dale J, Keizer PD (1978) Importance of sediment working by the deposit-feeding polychaete Arenicola marina on the weathering rate of sediment-bound oil. J Fish Res Board Can 35:591-603

Heitkamp MA, Cerniglia CE (1987) Effects of chemical structure and exposure on the microbial degradation of polycyclic aromatic hydrocarbons in freshwater and estuarine ecosystems. Environ Toxicol Chem 6:535-546

Heitkamp MA, Franklin W, Cerniglia CE (1988) Microbial metabolism of polycyclic aromatic hydrocarbons: isolation and characterisation of a pyrene-degrading bacterium. Appl Environ Microbiol 54(10):2549-2555

Hinga KR, Pilson ME (1987) Persistence of benz[a]anthracene degradation products in an enclosed marine ecosystem. Environ Sci Technol 21(7):648-653

Hüttel M (1990) Influence of the lugworm Arenicola marina on porewater nutrient profiles of sand flat sediments. Mar Ecol Prog Ser 62:241-248

Kanaly RA, Harayama S (2000) Biodegradation of highmolecular-weight polycyclic aromatic hydrocarbons by bacteria. J Bacteriol 182(8):2059-2067

Karickhoff SW (1981) Semi-empirical estimation of sorption of hydrophobic pollutants on natural sediments and soils. Chemosphere 10(8):833-846

Krantzberg G (1985) The influence of bioturbation on physical, chemical and biological parameters in aquatic environments: a review. Environ Pollut Ser A 39:99-122

Kristensen E (1983) Ventilation and oxygen uptake by three species of Nereis (Annelida:Polychaeta). II. Effects of temperature and salinity changes. Mar Ecol Prog Ser 12:299-306

Kristensen E (1984) Life cycle, growth and production in estuarine populations of the polychaetes Neries virens and N. diversicolor. Holarct Ecol 7:249-256

Kristensen E (1988) Factors influencing the distribution of Nereid polychaetes in danish coastal waters. Ophelia 29(2):127-140

Kure LK (1997) Interactions between particle-bound organic pollutants and bioturbating macrofauna. $\mathrm{PhD}$ thesis, Institute of Biology, University of Odense

Landrum PF (1989) Bioavailability and toxicokinetics of polycyclic aromatic hydrocarbons sorbed to sediments for the amphipod Pontoporeia hoyi. Environ Sci Technol 23: 588-595

Landrum PF, Nihart SR, Eadie BJ, Herche LR (1987) Reduction in the bioavailability of organic contaminants to the amphipod Pontoporeia hoyi by dissolved organic matters of sediment interstitial waters. Environ Toxicol Chem 6:11-20

Lee RF, Singer SC (1980) Detoxifying enzymes system in marine polychaetes; increases in activity after exposure to aromatic hydrocarbons. Rapp P-V Reun Cons Int Explor Mer 179:29-32

Lee RF, Singer SC, Tenore KR, Gardner SG (1979) Detoxification system in polychaete worms: importance in the degradation of sediment hydrocarbons. In: Vernberg WB, Thurberg FB, Calabrese A, Vernberg FJ (eds) Marine pollution: functional responses. Academic Press, New York, p 23-37

May EM, Wasik SP (1978) Determination of the solubility behaviour of some polycyclic aromatic hydrocarbons in water. Anal Chem 50:997-1000

Editorial responsibility: Hans Ulrik Riisgård (Contributing Editor), Kerteminde, Denmark
Means JC, Wood SG, Hassett JJ, Banwart WL (1980) Sorption of polynuclear aromatic hydrocarbons by sediments and soils. Environ Sci Technol 14(12):1524-1528

McElroy AE (1985) In vivo metabolism of benz[a]antrachene by the polychaete Nereis virens. Mar Environ Res 17: 133-136

McElroy AE (1990) Polycyclic aromatic hydrocarbon metabolism in the polychaete Nereis virens. Aquat Toxicol 18: $35-50$

McElroy AE, Sisson JD (1989) Trophic transfer of benzo[a]pyrene metabolites between benthic marine organisms. Mar Environ Res 28:265-269

McElroy AE, Farrington JW, Teal JM (1990) Influence of mode of exposure and the presence of a tubiculous polychaete on the fate of benz[a]antrachene in the benthos. Environ Sci Technol 24:1648-1655

Neff JM (1985) Polycyclic aromatic hydrocarbon. In: Rand GM, Petrocelli SR (eds) Fundamental of aquatic toxicology methods and applications. Hemisphere, Washington, DC, p 416-454

Payne JF, May N (1979) Further studies on the effect of petroleum hydrocarbons on mixed-function oxidases in marine organisms: pesticide and xenobiotic metabolism in marine organisms. ACS (Am Chem Soc) Symp Ser 99:339-347

Rasmussen AD, Banta GT, Andersen O (1998) Effects of bioturbation by the lugworm Arenicola marina on cadmium uptake and distribution in sandy sediments. Mar Ecol Prog Ser 164:179-188

Rehmann K, Noll HP, Steinberg CEW, Kettrup AA (1998) Pyrene degradation by Mycobacterium sp. strain KR2. Chemosphere 36(14):2977-2992

Reynoldson TB (1987) Interaction between sediment contaminants and benthic organisms. Hydrobiologia 149:53-66

Riisgård HU, Banta GT (1998) Irrigation and deposit feeding by the lugworm Arenicola marina, characteristics and secondary effects on the environment: a review of current knowledge. Vie Milieu 48:243-257

Riisgård HU, Berntsen I, Tarp B (1996) The lugworm (Arenicola marina) pump: characteristics, modelling and energy costs. Mar Ecol Prog Ser 138:149-156

Rossi SS, Neff JM (1978) Toxicity of polynuclear aromatic hydrocarbons to the polychaete Neanthes arenaceodentata. Mar Pollut Bull 9:220-223

Schaffner LC, Dickhut RM, Siddhartha M, Lay PW, BrouwerRiel C (1997) Effects of physical chemistry and bioturbation by estuarine macrofauna on the transport of hydrophobic organic contaminants in the benthos. Environ Sci Technol 31:3120-3125

Timmermann K, Christensen JH, Banta GT (2002) Modeling of advective transport in sandy sediments inhabited by the lugworm Arenicola marina. J Mar Res 60:151-169

Vedel A (1997) The biology of suspension-feeding in the polychaete Nereis diversicolor-ecological impact in coastal marine areas. PhD thesis, Institute of Biology, University of Odense

Wells GP (1966) The lugworm (Arenicola) — a study in adaptation. Neth J Sea Res 3(2):294-313

Weston DP (1990) Hydrocarbon bioaccumulation from contaminated sediment by the deposit-feeding polychaete Abarenicola pacifica. Mar Biol 107:159-169

Zar JH (1984) Biostatistical analysis, 2nd edn. Prentice-Hall, Englewood Cliffs, NJ

Submitted: November 15, 2001; Accepted: March 26, 2002

Proofs received from author(s): June 24, 2002 